Огляди літератури, оригінальні дослідження, погляд на проблему, випадок з практики, короткі повідомлення УДК 616.895.4-052:616.89-008.15-008.44-008.46

DOI 10.11603/1811-2471.2020.v.i3.11280

\title{
СОЦІАЛЬНО-ДЕМОГРАФІЧНІ ТА КЛІНІКО-АНАМНЕСТИЧНІ ПРЕДИКТОРИ КОГНІТИВНИХ ПОРУШЕНЬ ПРИ ДЕПРЕСІЯХ РІЗНОГО ҐЕНЕЗУ
}

๑С. О. Ярославцев

\begin{abstract}
Комунальне некомерційне підприємство «Херсонський обласний заклад з надання психіатричної
\end{abstract} допомоги Херсонської обласної ради»

PЕЗЮМЕ. Актуальність вивчення депресивних розладів обумовлена, з одного боку, їх поширеністю, а з іншого - їх медико-соціальними наслідками: суїцидальна поведінка, зниження соціального функціонування та якості життя.

Мета - визначити соціально-демографічні та клініко-анамнестичні предиктори когнітивних порушень при депресіях різного ґенезу.

Матеріал і методи. Було обстежено 362 пацієнтів із когнітивними порушеннями при депресивних розладах: 123 пацієнти з рекурентними депресивними розладами (РДР), 141 пацієнт з біполярними афективними розладами (БАР) та 98 осіб з пролонгованою депресивною реакцією (ПДР). Використовували комплекс методів дослідження: клініко-психопатологічний, психодіагностичний (тест запам'ятовування 10 слів А. Р. Лурія) та статистичний.

Результати. Були визначені соціально-демографічні та клініко-анамнестичні предиктори когнітивних порушень при депресіях різного ґенезу, які в перспективі можуть бути діагностичними критеріями при проведенні диференційної діагностики.

Висновки. Встановлені особливості мнестичних порушень при різних типах депресивних розладів: при РДР мнестичні порушення окреслювались зниженням рівня короткострокової пам'яті (4,32 бала) та переважанням помірних порушень відстроченого відтворення (50,41 \%); при БАР мнестичні порушення визначались зниженням рівня короткострокової пам'яті (4,52 бала) та переважанням середнього та зниженого рівнів відстроченого відтворення (49,65 та 21,99 \% відповідно); при ПДР відзначався нормативний рівень короткострокової пам'яті (5,37 бала) та переважання високого рівня відстроченого відтворення (58,16 \%).

КЛЮчОВІ СЛОВА: пацієнти з когнітивними порушеннями; депресивні розлади; мнестичні процеси; рекурентний депресивний розлад; біполярний депресивний розлад; пролонгована депресивна реакція.

Вступ. Актуальність вивчення депресивних розладів обумовлена, з одного боку, їх поширеністю, а з іншого - їх медико-соціальними наслідками (суїцидальна поведінка, зниження соціального функціонування та якості життя) [1]. У світі нараховується 264 мільйони осіб із депресією, в Україні також ця патологія в структурі поширеності займає провідне місце [2].

Депресія $\epsilon$ провідною причиною інвалідності у всьому світі і головним внеском у загальний глобальний тягар хвороб $[3,4]$. При найгіршому сценарії депресія може призводити до самогубства або розвитку тяжких соматичних захворювань [1-3]. Депресія збільшує ризик самогубства в 4 рази. Близько 15 \% хворих на депресію здійснюють суїцид [2, 3]. У 60 \% випадків причиною самогубств $\epsilon$ депресії $[1,2,5]$. Але $\epsilon$ і більш «легкі» ускладнення. Новим наслідком затяжної депресії вчені назвали погіршення пам'яті $[6,7]$. Під час епізодів депресії здатність мозку формувати нові клітини знижується. Багато пацієнтів і депресією відзначають зниження пам'яті, яке обумовлено не стільки афективними розладами, скільки загальним дисфункціональним станом психіки. Проте $\epsilon$ і специфічні для депресії мнестичні розлади, які виявляються в пробах на вільне відтворення і контрольоване розпізнавання. Відповідно до сучасних поглядів, робоча пам'ять $\epsilon$ центральною інстанцією виконавчих функцій, оскільки тут акумулюється вся поточна інформація, необхідна для збереження цільових установок, гнучкої зміни тактики поведінки, а також гальмування надлишкової інформації $[2,7]$. При тривалому депресивному розладі пацієнти можуть страждати від серйозних когнітивних порушень (КП), які позбавляють можливості незалежно функціонувати на роботі або в повсякденному житті $[3,5,7-10]$. у таких пацієнтів відзначаються проблеми із запам'ятовуванням нової інформації; зі здатністю до міркувань і виконання складних завдань; порушуються зорово-просторові функції, усна або письмова мова; відзначаються розлади в емоційно-вольовій сфері та поведінці $[6,7,10]$.

Останніми роками доведено, що серед причин порушення якості життя основними $\epsilon$ когнітивні розлади. У дослідженнях останнього періоду підтверджено, що когнітивний дефіцит при депресії, поряд із емоційними порушеннями, істотно погіршує соціальне функціонування при ДР, призводить до рецидивів захворювання та знижує якість життя пацієнтів $[3,9]$. На сучасному етапі відсутні систематизовані уявлення щодо специфіки когнітивних дисфункцій при різних типах депресивних розладів (ДР). Тому оцінка особли- 
Огляди літератури, оригінальні дослідження, погляд на проблему, випадок з практики, короткі повідомлення востей КП при різних типах депресії дозволить систематизувати та покращити знання щодо специфіки когнітивного дефіциту при депресіях різного ґенезу, які можуть виступати в якості діагностичних критеріїв при проведенні диференційної діагностики ДР.

Мета - визначити соціально-демографічні та клініко-анамнестичні предиктори когнітивних порушень при депресіях різного ґенезу.

Матеріал і методи дослідження. Проведене суцільне обстеження 362 пацієнтів з КП при ДР. Критеріями включення пацієнтів у групу дослідження були усвідомлення та підписання форми поінформованої згоди на участь у дослідженні; наявність поточного депресивного епізоду в рамках психіатричних діагнозів за діагностичними критеріями MKX-10: депресивний епізод (F 32.1-F 32.2), рекурентний депресивний розлад (F 33.1-F 33.2), біполярний афективний розлад (F 31.3-31.4) та розлади пристосувальних реакцій (F 43.20-43.21) середнього та тяжкого ступенів; наявність когнітивних порушень, визначених при бесіді з пацієнтом; вік від 18 до 65 років; відсутність декомпенсованої тяжкої соматичної патології. Критеріями виключення були депресивний стан у рамках інших нозологій (депресії при шизофренії, органічні та соматогенні депресії); небажання або нездатність пацієнта підписати інформовану згоду на участь у дослідженні; вагітність, годування грудьми. Усі обстежені були поділені на три групи порівняння за механізмом розвитку ДР, що встановлювався при клінічному інтерв'ю та динамічному спостереженні. Порівняльний аналіз проводили серед 123 паці-

єнтів із рекурентними депресивними розладами (РДР), 141 пацієнта з біполярними афективними розладами (БАР) та 98 пацієнтів з пролонгованою депресивною реакцією (ПДР).

У дослідженні був використаний комплексний підхід, що полягав у використанні клініко-психопатологічного, психодіагностичного («Заучування 10 слів» (А. Р. Лурія)) та статистичного методів дослідження [11]. Статистична обробка даних застосовувалась для визначення середніх величин кількісних параметрів, їхніх стандартних помилок (у форматі \% \pm \%), достовірності відмінностей (критерії Стьюдента - Фішера [t], Колмогорова - Смірнова $[\lambda])$. Статистичну обробку результатів проводили за допомогою Excel-2010 та STATISTICA 6.1.

Результати й обговорення. Соціально-демографічна характеристика пацієнтів з КП при ДР включала розподіл за віком, статтю, рівнем освіти, сімейним станом, характером і сферою професійної діяльності та місцем проживання.

Серед обстежених пацієнтів з РДР було 57 чоловіків $(46,34 \pm 2,78)$ \% і 66 жінок $(53,66 \pm 2,99) \%$, серед пацієнтів з БАР було 76 чоловіків $(53,90 \pm$ $2,61) \%$ та 65 жінок $(46,10 \pm 2,42) \%$, а серед пацієнтів з ПДР було 43 чоловіки $(43,88 \pm 3,39) \%$ та 55 жінок $(56,12 \pm 3,83) \%$, що в цілому відповідає типовому розподілу за статтю при ДР (табл. 1). Статистичний аналіз результатів дозволив визначити, що в групі пацієнтів з БАР чоловіків було більше (53,90\%, ДК=0,66, MІ=0,02, p=0,046), ніж у групі пацієнтів із РДР $(53,66 \%$, ДК=0,66, MI=0,02, $\mathrm{p}=0,046)$ та ПДР $(56,12 \%, Д К=0,85, M l=0,04, p=0,033)$, де було більше жінок.

Таблиця 1. Розподіл пацієнтів з когнітивними порушеннями при депресивних розладах за віком і статтю

\begin{tabular}{|c|c|c|c|c|c|c|}
\hline \multirow[t]{2}{*}{ Показник } & \multicolumn{2}{|c|}{$\begin{array}{c}\text { РДР } \\
\mathrm{N}=123\end{array}$} & \multicolumn{2}{|c|}{$\begin{array}{c}\text { БАР } \\
N=141\end{array}$} & \multicolumn{2}{|c|}{$\begin{array}{c}\text { ПДР } \\
\mathrm{N}=98\end{array}$} \\
\hline & a6c. & $\% \pm m \%$ & a6c. & $\% \pm m \%$ & a6c. & $\% \pm m \%$ \\
\hline \multicolumn{7}{|c|}{ Стать } \\
\hline Чоловіки & $57^{1}$ & $46,34 \pm 2,78$ & $76^{2}$ & $53,90 \pm 2,61$ & 43 & $43,88 \pm 3,39$ \\
\hline Жінки & $66^{1}$ & $53,66 \pm 2,99$ & $65^{2}$ & $46,10 \pm 2,42$ & 55 & $56,12 \pm 3,83$ \\
\hline \multicolumn{7}{|c|}{ Вік } \\
\hline 18-29 років & $4^{1}$ & $3,25 \pm 0,26$ & $44^{2}$ & $31,21 \pm 1,85$ & $21^{3}$ & $21,43 \pm 1,96$ \\
\hline 30-44 років & 52 & $42,28 \pm 2,63$ & 52 & $36,88 \pm 2,09$ & 34 & $34,69 \pm 2,89$ \\
\hline 45-59 років & $46^{1}$ & $37,40 \pm 2,43$ & 37 & $26,24 \pm 1,61$ & 29 & $29,59 \pm 2,56$ \\
\hline 60-65 років & $21^{1}$ & $17,07 \pm 1,27$ & $8^{2}$ & $5,67 \pm 0,39$ & 14 & $14,29 \pm 1,36$ \\
\hline
\end{tabular}

Примітки: 1 - вірогідність розбіжностей р<0,05 між РДР та БАР; 2 - вірогідність розбіжностей р<0,05 між БАР та ПДР; 3 - вірогідність розбіжностей р<0,05 між РДР та ПДР.

Серед пацієнтів з КП при ДР переважали особи зрілого (30-44 років) та середнього (45-59 років) віку: при рекурентній депресії - 42,28 \% та $37,40 \%$ відповідно, при біполярній депресії $36,88 \%$ та $26,24 \%$ відповідно, в групі пацієнтів 3
ПДР - 34,69 \% та 29,59 \% відповідно. Також було зафіксовано, що серед пацієнтів з РДР було $17,07 \%$ осіб похилого віку (60-65 років), а серед пацієнтів з БАР та ПДР - 31,21\% та 21,43 \% осіб молодого віку відповідно. 
Огляди літератури, оригінальні дослідження, погляд на проблему, випадок з практики, короткі повідомлення

Статистичний аналіз вікового розподілу пацієнтів з КП при ДР продемонстрував, що осіб молодого віку (18-29 років) було більше серед пацієнтів з ПДР (21,43\%) та серед пацієнтів з БАР (31,21\%), ніж при РДР $(3,25 \%$, ДК=8,19, Ml=0,74, $\mathrm{p}=0,0001$ та ДК=9,82, Ml=1,37, $\mathrm{p}=0,0001$ відповідно). Особи середнього віку (45-59 років) переважали серед хворих на РДР $(37,40 \%)$, порівняно $з$ пацієнтами з БАР $(26,24 \%$, ДК=1,54, Ml=0,09, $\mathrm{p}=0,016)$. Особи похилого віку (60-65 років) переважали серед пацієнтів з РДР $(17,07 \%)$ та пацієнтів з ПДР (14,29\%), порівняно з пацієнтами з БАР $(5,67 \%, Д К=4,78, M I=0,27, p=0,002$ та ДК=4,01, $\mathrm{Ml}=0,17, \mathrm{p}=0,014$ відповідно).

За рівнем освіти у пацієнтів з КП при ДР переважали особи з середньою спеціалізованою $(33,25 \%)$ та неповною вищою освітою $(33,26 \%)$. Більшість обстежених - мешканці міста (66,46 \%), одружені (34,91\%), серед пацієнтів з ПДР було більше самотніх осіб (41,84\%), серед пацієнтів $з$ РДР та БАР - розлучених осіб (21,95 \% та 26,95\% відповідно). Серед пацієнтів з КП при ДР переважали особи, які працювали $(48,63 \%)$ і займалися переважно розумовою працею $(61,22 \%), 29,58 \%$ осіб були безробітними, 21,77 \% - пенсіонерами. Кількість осіб із фізичним характером праці була більшою серед пацієнтів з ПДР (54,72 \%), порівняно з РДР та БАР (36,21 \% та 25,40 \% відповідно), серед них переважали пацієнти з розумовим характером праці (63,79 \% та 74,60 \% відповідно) та було більше осіб, що вийшли на пенсію $(27,64 \%$ та 23,40 \% відповідно).

Аналіз спадкової обтяженості пацієнтів з КП при ДР дозволив визначити, що хворі з РДР та БАР характеризувались наявністю спадкової обтяженості переважно соматичними захворюваннями $((28,46 \pm 1,97) \%$ та $(22,70 \pm 1,43) \%$ відповідно), депресивними розладами $((21,95 \pm 1,59) \%$ та $(19,15 \pm 1,23)$ \% відповідно) та алкогольною залежністю $((17,07 \pm 1,27) \%$ та $(18,44 \pm 1,19) \%$ відповідно). у $24,49 \%$ пацієнтів з ПдР відмічалась спадкова обтяженість алкогольною залежністю, у 23,47 \% осіб - соматичними захворюваннями та у $18,37 \%$ особистісними аномаліями у родичів.

Серед екзогенно-органічних уражень в анамнезі у пацієнтів з РДР переважали патологія пологів $((13,01 \pm 0,99) \%)$ та різні види інтоксикації в анамнезі $((11,38 \pm 0,88) \%)$, у пацієнтів з БАР - патологія вагітності й пологів $((14,18 \pm 0,94) \%$ та $(17,02 \pm 1,11) \%$ відповідно) та інтоксикації в анамнезі $((12,77 \pm 0,85) \%)$, у пацієнтів з ПДР - патологія пологів $((11,22 \pm 1,09) \%)$.

Статистичний аналіз результатів дозволив визначити, що спадкова обтяженість депресивними розладами відрізняла пацієнтів з РДР і БАР від хворих з ПДР $(21,95 \%, Д К=3,33, M l=0,20, p=0,009$ та
$19,15 \%$, ДК=2,73, Ml=0,12, $\mathrm{p}=0,024$ відповідно), серед яких було більше пацієнтів зі спадковою обтяженістю у вигляді особистісних аномалій у родичів $(8,13 \%$, ДК=3,54, Ml=0,18, $\mathrm{p}=0,012$ та 9,93\%, ДК=2,67, $\mathrm{Ml}=0,11, \mathrm{p}=0,026$ відповідно). Також було встановлено, що пацієнти з БАР відрізнялись від пацієнтів з ПДР більшою кількістю осіб зі спадковою обтяженістю психічними розладами у родичів $(17,02 \%$, ДK=3,19, $\mathrm{Ml}=0,14, p=0,021)$ та наявністю екзогенноорганічних уражень в анамнезі у вигляді патології вагітності (14,18\%, ДК=5,41, Ml=0,27, $\mathrm{p}=0,005)$.

Дослідження процесу запам'ятовування у пацієнтів з КП при ДР продемонструвало, що у хворих на РДР рівень короткострокової пам'яті був знижений та становив $(4,32 \pm 2,19)$ слова, при нормі $7 \pm 2$ (рис. 1). Також було визначено, що процес запам'ятовування був неповним та не досягав повного обсягу слів, які необхідно було запам'ятати і становив $(9,11 \pm 1,56)$ слів при 10-тій спробі. У паці$\epsilon$ нтів з БАР також рівень короткострокової пам'яті був нижчий за норму та становив $(4,52 \pm 2,78)$ слів (при $\mathrm{N}=7 \pm 2$ ), а процес запам'ятовування був неповним та становив при 10 -ій спробі $(8,57 \pm 1,97)$ слів. У пацієнтів з ПДР рівень короткострокової пам'яті був у нижніх межах норми - $(5,37 \pm 1,06)$ слів, а процес запам'ятовування був неповним та становив $(9,57 \pm 0,58)$ слів.

У всіх пацієнтів з КП при ДР фіксувалася наявність «плато» запам'ятовування, інколи - наявність "крайового ефекту» або навіть зменшення кількості слів, що відтворювалися. Такі феномени були відображенням незацікавленості пацієнта в обстеженні, загальної емоційної загальмованості та підвищеної стомлюваності. Виявлення такого феномену у пацієнтів з ДР додатково свідчить на користь негативного впливу депресивного синдрому на функціональний стан головного мозку.

Статистичний аналіз результатів продемонстрував відмінності між групами, які полягали у більш низькому рівні короткострокової пам'яті у пацієнтів з РДР $(4,32 \pm 2,19)$ та БАР $(4,52 \pm 2,78)$, порівняно з хворими на ПДР $(5,37 \pm 1,06, p<0,025$ та p $<0,048$ відповідно). Також було визначено, що рівень мнестичних процесів виявився вищим у пацієнтів з ПДР $(9,57 \pm 0,58)$, порівняно з хворими на БАР $(8,57 \pm 1,97, \mathrm{p}<0,027)$. Також аналізували особливості процесу запам'ятовування: у пацієнтів 3 ПДР фіксувалась більша кількість слів, що запам'ятовувалась, на 2-й, 3-й, 5-й та 8-й спробах, порівняно з пацієнтами з РДР $(5,16 \pm 1,88, p<0,025 ; 6,03 \pm 2,01$, $p<0,0001 ; 6,89 \pm 1,22, p<0,035$ та 7,89 $\pm 1,34, p<0,01)$ та БAP $(4,67 \pm 2,13, p<0,001 ; 5,04 \pm 1,87, p<0,0001 ; 6,29 \pm$ $1,38, p<0,0025$ та $8,21 \pm 1,15, p<0,021)$, що свідчить про те, що пацієнти з ПДР швидше мобілізуються на початкових етапах та включаються до роботи при виконанні тесту. 
Огляди літератури, оригінальні дослідження, погляд на проблему, випадок з практики, короткі повідомлення

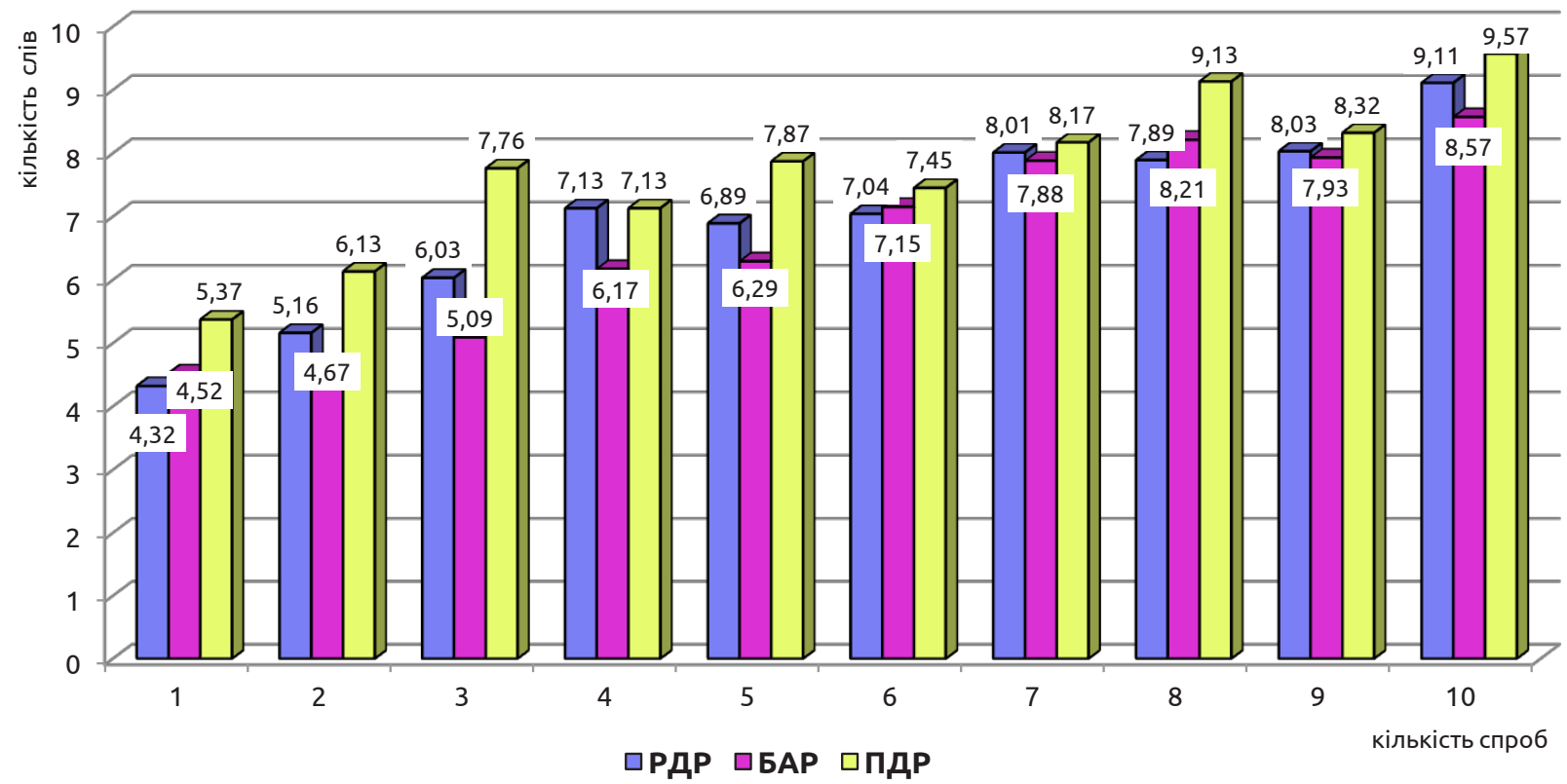

Рис. 1. Особливості процесу запам'ятовування у хворих з когнітивними порушеннями при депресивних розладах.

Також був досліджений процес відстроченого відтворення, який визначався за наступними критеріями: високий рівень визначався, коли пацієнт відтворював 8-9 слів (із 10-и), середній рівень - у разі відтворення 5-7 слів, нижче середнього рівня - при відтворенні 3-4 слів та низький рівень при відтворенні лише до 2-х слів. Результати цього аналізу представлені в таблиці 2, з якої видно, що у більшості пацієнтів з РДР був встановлений середній рівень відстроченого відтворення $(50,41 \pm 2,91) \%$, у $38,21 \%$ - високий рівень, у 9,76\% осіб цей рівень був нижче середнього та у $1,63 \%$ осіб - низьким.

Таблиця 2. Рівень відстроченого відтворення у пацієнтів з когнітивними порушеннями при депресивних розладах

\begin{tabular}{|l|c|c|c|c|c|c|}
\hline \multirow{2}{*}{\multicolumn{1}{|c|}{ Показник }} & \multicolumn{2}{|c|}{ РДР $(\mathrm{n}=123)$} & \multicolumn{2}{c|}{ БАР $(\mathrm{n}=141)$} & \multicolumn{2}{c|}{ ПДР $(\mathrm{n}=98)$} \\
\cline { 2 - 7 } & $\mathrm{aбc.}$ & $\% \pm \mathrm{m} \%$ & $\mathrm{a} \mathrm{c}$. & $\% \pm \mathrm{m} \%$ & aбc. & $\% \pm \mathrm{m} \%$ \\
\hline Високий рівень & 47 & $38,21 \pm 2,46$ & 36 & $25,53 \pm 1,57$ & 57 & $58,16 \pm 3,88$ \\
\hline Середній рівень & 62 & $50,41 \pm 2,91$ & 70 & $49,65 \pm 2,52$ & 28 & $28,57 \pm 2,49$ \\
\hline Нижче середнього & 12 & $9,76 \pm 0,76$ & 31 & $21,99 \pm 1,39$ & 11 & $11,22 \pm 1,09$ \\
\hline Низький рівень & 2 & $1,63 \pm 0,13$ & 4 & $2,84 \pm 0,20$ & 2 & $2,04 \pm 0,21$ \\
\hline
\end{tabular}

У 25,53 \% хворих на БАР був зафіксований високий рівень відстроченого відтворення, у $49,65 \%$ - середній, у 21,99 \% - нижче середнього та у $2,84 \%$ - низький.

у більшості пацієнтів з ПДР відмічався високий рівень відстроченого відтворення $(58,16 \pm$ $3,88) \%$ у у $28,57 \%$ пацієнтів був встановлений середній рівень, у $11,22 \%$ осіб - нижче середнього та у 2,04 \% пацієнтів - низький рівень відстроченого відтворення.

Статистичний аналіз продемонстрував, що серед пацієнтів з ПДР було більше осіб з високим рівнем відстроченого відтворення (58,16\%), порівняно з пацієнтами з РДР $(38,21 \%$, ДК=1,82, MI=0,18, $p<0,001)$ та БАР $(25,53 \%, Д K=3,58, M l=0,58$, p<0,0001), при цьому серед пацієнтів із РДР було більше осіб із високим рівнем відстроченого відтворення, ніж при БАР (ДК = 1,75, MI =0,11, $\mathrm{p}<0,009)$. Також було доведено, що серед пацієнтів з РДР та БАР було більше осіб із середнім рівнем відстроченого відтворення (50,41 \% та 49,65 \% відповідно), порівняно з пацієнтами з ПДР $(28,57 \%$, ДК=2,47, $\mathrm{Ml}=0,27, \mathrm{p}<0,0004$ та $Д К=2,40, \mathrm{Ml}=0,25, \mathrm{p}<0,0005)$. Серед пацієнтів з БАР було більше осіб із рівнем відстроченого відтворення нижче середнього (21,99\%), порівняно з пацієнтами з РДР та ПДР $(9,76 \%, Д К=3,53, M \mathrm{l}=0,22, \mathrm{p}<0,003$ та $11,22 \%$, ДК=2,92, Мl=0,16, $\mathrm{p}<0,014$ відповідно).

Висновки. 1. Визначені соціально-демографічні показники пацієнтів з КП при ДР. Встановле- 
Огляди літератури, оригінальні дослідження, погляд на проблему, випадок з практики, короткі повідомлення но, що серед обстежених переважали особи жіночої статі (51,96 \%), лише в групі пацієнтів з БАР було більше чоловіків (53,90\%); переважали особи 3044 років (38,12\%). Осіб молодого віку (18-29 років) було більше серед пацієнтів з ПДР $(21,43 \%)$ та серед хворих з БАР $(31,21 \%)$, а осіб середнього віку (45-59 років) та осі6 похилого віку (60-65 років) серед пацієнтів з РДР $(37,40 \%$ та $17,07 \%)$.

2. Встановлені особливості спадкової обтяженості, що полягали в переважанні спадкової обтяженості основного захворювання соматичною патологією (24,86\%), алкогольною залежністю (19,61 \%) та ДР у родичів (17,68 \%). При цьому, спадкова обтяженість ДР відрізняла пацієнтів 3 РДР і БАР від хворих з ПДР (21,95 \%, р=0,009 та $19,15 \%, p=0,024$ відповідно), серед яких було більше пацієнтів зі спадковою обтяженістю у вигляді особистісних аномалій у родичів (8,13\%, p=0,012 та 9,93\%, p=0,026 відповідно).

3. Визначені особливості мнестичних порушень при різних типах ДР: при РДР мнестичні по-

рушення окреслювались зниженням рівня короткострокової пам'яті (4,32 бала) та переважанням помірних порушень відстроченого відтворення (50,41 \%); при БАР мнестичні порушення визначались зниженням рівня короткострокової пам'яті (4,52 бала) та переважанням середнього та зниженого рівнів відстроченого відтворення (49,65 та 21,99 \% відповідно); при ПДР відзначалися нормативний рівень короткострокової пам'яті (5,37 балів) та переважання високого рівня відстроченого відтворення (58,16 \%);

Перспективи подальших досліджень. У результаті дослідження були визначені соціальнодемографічні та клініко-анамнестичні предиктори когнітивних порушень при депресіях різного ґенезу, які в перспективі можуть бути використані як діагностичні критерії при проведенні диференційної діагностики, а також визначені КП можуть бути мішенями психосоціальної реабілітації пацієнтів із різними формами ДР.

\section{ЛІТЕРАТУРА}

1. Комплексный план действий в области психического здоровья на 2013-2020 гг. [Электронный ресурс]. Женева : ВОО3, 2013. - Режим доступа: http://арps.who. int/gb/ebwha/pdf_files/WHA66/A66_R8-ru.pdf?ua=1.

2. Hasselbalch B. J. Cognitive impairment in the remitted state of unipolar depressive disorder: A systematic review / B. J. Hasselbalch, U. Knorr, L. V. Kessing // J. Affect. Disord. - 2011. - Vol. 134. - P. 20-31.

3. Діагностичні критерії депресивних розладів на етапах надання медичної допомоги: тези доповідей $\mathrm{V}$ Національного конгресу неврологів, психіатрів та наркологів України з міжнародною участю «Неврологічна, психіатрична та наркологічна допомога в Україні: тенденції розвитку та сучасні виклики». Україна, Харків, 1617 березня 2017 р. / Н. О. Марута, Т. В. Панько, В. Ю. Федченко [та ін.] // Український вісник психоневрології. 2017. - Т. 25, Вип. 1 (90). - С. 135.

4. Кривоніс Т. Г. Гендерні особливості прояву клініко-психологічних феноменів у онкологічних пацієнтів / Т. Г. Кривоніс, І. В. Жулкевич // Здобутки клінічн. і експеримен. медицини. - 2020. - № 1. - C. 115-119. https:// doi.org/10.11603/1811-2471.2020.v.i1.11078.

5. Шафранський В. В. Психічне здоров'я населення України: стан, проблеми та шляхи вирішення / В. В. Шафранський, С. В. Дудник // Україна. Здоров'я Нації. - 2016. №. 3 (39). - С. 12-18.

\section{REFERENCES}

1. Zheneva. WHO (2013). Kompleksnyy plan deystviy v oblasti psikhicheskogo zdorov'ya na 2013-2020 gg. [Comprehensive mental health action plan 2013-2020]. Retrieved from: http://apps.who.int/gb/ebwha/pdf_files/WHA66/ A66_R8-ru.pdf?ua=1 [in Russian].

6. Cognitive deficits and functional outcomes in major depressive disorder: determinants, substrates, and treatment interventions / R. S. Mclntyre, D. S. Cha, J. K. Soczynska [et al.] // Depress. Anxiety. - 2013. - Vol. 30 (6). P. 515-527.

7. Iverson G. L. Rapid screening for perceived cognitive impairment in major depressive disorder / G. L. Iverson, R. W. Lam // Ann. Clin. Psychiatry. - 2013. - Vol. 25 (2). P. $135-140$.

8. Марута Н. А. Депрессивные расстройства у жителей сельской местности (клинико-психопатологическая характеристика, диагностика и лечение) : монография / Н. А. Марута, Ж. И. Матвиенко, И. Л. Вовк. - К. : ООО «Печатная Лавка», 2011. - 146 с.

9. Влияние тревоги на когнитивные процессы при депрессивном синдроме / М. В. Алфимова, И. А. Лапин, Е. В. Аксенова, Т. С. Мельникова // Социальная и клиническая психиатрия. - 2017. - Vol. 27 (1). - P. 5-12.

10. Gotlib H. Cognition and depression: current status and future directions / H. Gotlib, J. Joormann // Annu. Rev. Clin. Psychol. - 2010. - Vol. 6. - P. 285-312.

11. Лурия А. Р. Методика «Заучивание 10 слов» / А. Р. Лурия // Альманах психологических тестов. - М., 1995. - С. 92-94.

2. Hasselbalch, B.J., Knorr, U., \& Kessing, L.V. (2011). Cognitive impairment in the remitted state of unipolar depressive disorder: A systematic review. J. Affect. Disord., 134, 20-31.

3. Maruta, N.O., Panko, T.V., Fedchenko, V.Yu., Semikina, O.Ye., Kalenska, H.Yu., \& Terenkovskyi, D.I. (2017). Di- 
Огляди літератури, оригінальні дослідження, погляд на проблему, випадок з практики, короткі повідомлення ahnostychni kryteriii depresyvnykh rozladiv na etapakh nadannia medychnoi dopomohy: tezy dopovidei V-ho Natsionalnoho konhresu nevrolohiv, psykhiatriv ta narkolohiv Ukrainy z mizhnarodnoiu uchastiu "Nevrolohichna, psykhiatrychna ta narkolohichna dopomoha v Ukraini: tendentsii rozvytku ta suchasni vyklyky". Ukraina, Kharkiv, 16-17 bereznia 2017 r. [Diagnostic criteria for depressive disorders at the stages of medical care: abstracts of the $V$ National Congress of Neurologists, Psychiatrists and Narcologists of Ukraine with international participation "Neurological, psychiatric and narcological aid in Ukraine: development tendencies and modern challenges» Ukraine, Kharkiv, March 16-17, 2017]. Ukrainskyi visnyk psykhonevrolohii - Ukrainian Bulletin of Psychoneurology, 25, 1 (90), 135 [in Ukrainian].

4. Krivonis, T.G., \& Zhulkevych, I.V. (2020). Henderni osoblyvosti proiavu kliniko-psykholohichnykh fenomeniv u onkolohichnykh patsiientiv [Gender features of clinicalpsychological phenomena in cancer patients]. Zdobutky klinichn. i eksperymen. Medytsyny-Achievements of Clinical and Experimental Medicine, (1), 115-119. Retrieved from: https://doi.org/10.11603/1811-2471.2020.v.i1.11078 [in Ukrainian].

5. Shafranskyi, V.V., \& Dudnyk S.V. (2016) Psykhichne zdorovia naselennia Ukrainy: stan, problemy ta shliakhy vyrishennia [Mental health of the population of Ukraine: status, problems and solutions]. Ukraina. Zdorovia NatsiiUkraine. Nation's Health, 3 (39), 12-18 [in Ukrainian].

6. Mclntyre, R.S., Cha, D.S., Soczynska, J.K., Woldeyo-

hannes, H.O., Gallaugher, L.A., Kudlow, P., Alsuwaidan, M., \& Baskaran, A. (2013). Cognitive deficits and functional outcomes in major depressive disorder: determinants, substrates, and treatment interventions. Depress. Anxiety, 30 (6), 515-527.

7. Iverson, G.L., \& Lam, R.W. (2013) Rapid screening for perceived cognitive impairment in major depressive disorder. Ann. Clin. Psychiatry, 25 (2), 135-140.

8. Maruta, N.A., Matviyenko, Zh.I., \& Vovk, I.L. (2011). Depressivnyye rasstroystva u zhiteley selskoy mestnosti (kliniko-psikhopatologicheskaya kharakteristika, diagnostika i lecheniye). Monografiya [Depressive disorders in rural residents (clinical and psychopathological characteristics, diagnosis and treatment). Monograph]. Kyiv: OOO "Pechatnaya Lavka" [in Russian].

9. Alfimova, M.V., Lapin, I.A., Aksenova, Ye.V., \& Melnikova, T.S. (2017). Vliyaniye trevogi na kognitivnyye protsessy pri depressivnom sindrome [The influence of anxiety on cognitive processes in depressive syndrome]. Sotsialnaya i klinicheskaya psikhiatriya - Social and Clinical Psychiatry, 27 (1), 5-12 [in Russian].

10. Gotlib, H., \& Joormann, J. (2010). Cognition and depression: current status and future directions. Annu. Rev. Clin. Psychol., 6, 285-312.

11. Luriya, A.R. (1995). Metodika "Zauchivaniye 10 slov" [Methodology "Learning 10 words"]. Almanakh psikhologicheskikh testov - Almanac of Psychological Tests, 92-94. Moscow [in Russian].

\title{
СОЦИАЛЬНО-ДЕМОГРАФИЧЕСКИЕ И КЛИНИКО-АНАМНЕСТИЧЕСКИЕ ПРЕДИКТОРЫ КОГНИТИВНЫХ НАРУШЕНИЙ ПРИ ДЕПРЕССИЯХ РАЗЛИЧНОГО ГЕНЕЗА
}

○С. А. Ярославцев

\author{
Коммунальное некоммерческое предприятие «Херсонское областное учреждение по оказанию
} психиатрической помощи Херсонского областного совета»

РЕЗЮМЕ. Актуальность изучения депрессивных расстройств обусловлена, с одной стороны, их распространенностью, а с другой - их медико-социальными последствиями: суицидальное поведение, снижение социального функционирования и качества жизни.

Цель - определить социально-демографические и клинико-анамнестические предикторы когнитивных нарушений при депрессиях различного генеза.

Материал и методы. Было обследовано 362 пациента с когнитивными нарушениями при депрессивных расстройствах: 123 пациента с рекуррентными депрессивными расстройствами (РДР), 141 пациент с биполярными аффективными расстройствами (БАР) и 98 пациентов с пролонгированной депрессивной реакцией (ПДР). Использовали комплекс методов исследования: клинико-психопатологический, психодиагностический (тест запоминания 10 слов А. Р. Лурия) и статистический.

Результаты. Были определены социально-демографические и клинико-анамнестические предикторы когнитивных нарушений при депрессиях различного генеза, которые в перспективе могут выступать в качестве диагностических критериев при проведении дифференциальной диагностики.

Выводы. Установлены особенности мнестических нарушений при различных типах депрессивных расстройств: при РДР мнестические нарушения очерчивались снижением уровня краткосрочной памяти (4,32 балла) и преобладанием умеренных нарушений отсроченного воспроизведения (50,41 \%); при БАР мнестические нарушения определялись снижением уровня краткосрочной памяти (4,52 балла) и преобладанием среднего и сниженного уровней отсроченного воспроизведения (49,65 и 21,99 \% соответственно); при ПДР отмечался нормативный уровень краткосрочной памяти (5,37 баллов) и преобладание высокого уровня отсроченного воспроизведения $(58,16 \%)$.

КЛЮЧЕВЫЕ СЛОВА: пациенты с когнитивными нарушениями; депрессивные расстройства; мнестические процессы; рекуррентное депрессивное расстройство; биполярное депрессивное расстройство; пролонгированная депрессивная реакция. 
Огляди літератури, оригінальні дослідження, погляд на проблему, випадок з практики, короткі повідомлення

SOCIO-DEMOGRAPHIC AND CLINICAL-ANAMNESTIC PREDICTORS OF COGNITIVE DISORDERS IN DEPRESSIONS OF DIFFERENT GENESIS

๑S. O. Yaroslavtsev

\section{Communal Nonprofit Enterprise "Kherson Regional Institution of Mental Care of Kherson Regional Council"}

SUMMARY. The relevance of the study of depressive disorders is due on the one hand to their prevalence, and on the other - their medical and social consequences (suicidal behavior, reduced social functioning and quality of life).

The aim of the study - to determine the socio-demographic and clinical-anamnestic predictors of cognitive disorders in depression of different genesis.

Material and Methods. 362 patients with cognitive impairment in depressive disorders were examined: 123 patients with recurrent depressive disorder (RDD), 141 patients with bipolar affective disorder (BAD) and 98 patients with prolonged depressive reaction (PDR). A set of research methods was used: clinical-psychopathological, psychodiagnostic (test of memorization of 10 words by A. R. Luria) and statistical.

Results. Socio-demographic and clinical-anamnestic predictors of cognitive disorders in depressions of different genesis were determined, which in the future may act as diagnostic criteria in the differential diagnosis.

Conclusions. Peculiarities of mnestic impairments in various types of depressive disorders were established: in $\mathrm{RDD}$, mnestic disorders were characterized by a decrease in the level of short-term memory (4.32 points) and the predominance of moderate level of delayed reproduction (50.41\%); in BAD, mnestic disorders were determined by a decrease in the level of short-term memory (4.52 points) and the predominance of medium and low levels of delayed reproduction ( 49.65 and $21.99 \%$, respectively); the normative level of short-term memory (5.37 points) and the predominance of a high level of delayed reproduction (58.16\%) were defined in PDR.

KEY WORDS: patients with cognitive disorders; depressive disorders; mnestic processes; recurrent depressive disorder; bipolar depressive disorder; prolonged depressive reaction.

Отримано 18.08 .2020 